\title{
The Spatial Artistic Model in Music
}

\section{Gómez AG*}

Universidad Michoacana de San Nicolás de Hidalgo, México

*Corresponding author: Arturo García Gómez, Universidad Michoacana de San Nicolás de Hidalgo, Santiago Tapia 403, Col. Centro, Morelia 58000, Michoacán México, Tel: 52443445 42 49; Email: artuchik@yahoo.com

\section{Research Article}

Volume 3 Issue 4

Received Date: September 07, 2020

Published Date: October 15, 2020

DOI: $10.23880 /$ phij-16000155

\section{Abstract}

The article is an overview of the aesthetic question of space in music. The study begins from the vague to evident perceptions of space in music in the analogy with the physical high pitch of sounds. These are associative sensations with the movement of things in the space like distance or rapprochement when the sound goes up and down. Then, the spatial character of pitch focused on the two-dimensionality of vertical and horizontal dimensions in music and the new spatial sensation similar to linear perspective in graphic arts that suggests an analogy of the space between painting and music. Next, the new concept of tonal gravitation like motion energy which moves from one tone to tone as the main reason for our musical space-sensation, so to speak, the sounding perspective with the force of tonal gravitation that produces the effect of depth or third dimension in music. Finally, our contribution to the spatial artistic model in the conception of musical contents as a reflection of human activity expressed by intonations, in which our imagination completes the spatial vacuum of music.

Keyword: Musical space; Musical perspective; Pure intuition; Intonation; Artistic model

All we know that music is the art of the time. In the Age of Enlightenment Gotthold Ephraim Lessing, examining the differences between beaux-arts, established the limits of painting and poetry by their type of dimensional representation, by space or by time:

Now the poet, as experience shows, can raise this degree of illusion in us, by the representation of other than visible objects. Consequently, artists are excluded from whole classes of pictures, which the poet has at his command. Dryden's "Ode upon Cecilia's day," is full of musical sketches, which afford no occupation to the brush; but I will not waste more time in such instances, from which we can only learn at best, that colors are not sounds, and ears, not eyes ${ }^{1}$.

Since then music was the art of time by excellence, ignoring the notion of space in this art. However, the notion of space in music doesn't refer to the place only in which it is performed but to its representation. Nevertheless, the

1 Gotthold Ephraim Lessing, Laocoon: An Essay on the Limits of Painting and Poetry, Translated from German by E. C. Beasley, London, 1853, p. 98. spatial representation in music is very much complex owing to its nature, and even more, because of the common idea that music is an abstract art without any representation.

Just like the notion of musical time as an inner experience, that is, as a pure form of intuition, the musical space is that form of intuition that perceives the things that appear externally but under the function of our internal sense. There is not the physical space that we perceive visually but the sonorous representation of space that we perceive internally just like the time. There is a sonorous space under the representation of a musical form.

Indeed, as much in the art as in science, space and time are indissoluble. Nothing in the world of physical objects, nor the world of subjective representations, subsist only in the space without time or endure only in the time outside space. Therefore, in the present aesthetics even speaks about the conceptual time or the sensation of time in painting or architecture and the perception of space in music. 


\section{Philosophy International Journal}

There are several types of spatial representation in music beginning from vague impressions to evident or welldefined perceptions of space, from abstract to concrete impressions, from straight to conditional relations, and from representations associated with the physical location of sound to the spatial characteristics of sound itself.

Hermann von Helmholtz was the first physicist that analyzed the space concerning the physical high-pitch of sounds or the spatial-vertical representation of pitch in his work: Die Lehre von den Tonempfindungen, als Physiologische Grundlage für die Theorie der Musik (1863). Helmholtz points out three aspects of musical scale similar to spatial properties.

First, the musical scale like the geometrical space is homogeneous as regards their form. Every melody or accord keeps their interval relation when it is transported to another place of the scale, just like geometrical objects keep their form while they are moving in the space. There is a constant in the spatial and sonorous transposition: "Every melodic phrase, every chord, which can be executed at any pitch, can be also executed at any other pitch in such a way that we immediately perceive the characteristic marks of their similarity"2.

Second, the sounds or voices produced separately at different levels of the musical scale are similar to the physical objects located in different places of the space. Finally, the movement of high-pitch sounds is easily associated with the spatial movement and therefore provokes certain sensations related to the movement in general.

Later, the German musicologist Carl Stumpf affirmed in his Tonpsychologie (1883) that the high-pitch of sounds and their timbre's changes at music scale, as well as the sensation of distance or rapprochement when the sound goes up and down, are associated with the movement of things in the space. Nevertheless, he points out that certain spatial qualities of sound have a physiological basis too. For example, the sensation of spaciousness in low pitches is connected with the ear's reaction to the wavelength of sound.

But these analogies between space and musical scale are based on the Newtonian concept of absolute space and time. For Isaac Newton, the natural philosophy ought to be an abstraction of senses. In his Philosophiae naturalis principia mathematica (1687), Newton affirms:

Absolute space, in its nature, without regard to anything external, remains always similar and immovable. Relative space is some movable dimension or measure of the absolute

2 Hermann L. F. Helmholtz. On the sensations of tone, Translated by Alexander J. Ellis. London-New York, 1895, p. 370. space; which our senses determine by its position to bodies [...] Absolute and relative space, are the same in figure and magnitude; but they do not always remain numerically the same $^{3}$.

In 1883 the Austrian physicist and philosopher Ernst Mach affirmed that the Newtonian absolute space is a purely mental construct, a conceptual form that cannot be produced in the experience ${ }^{4}$. In his criticism of experience (Empiriocriticism), Ernst Mach affirmed that the man is part of nature, and the language, like the science, is the result of natural evolution. Therefore, Mach proposes the notion of biological knowledge that conceives like a progressive adaptation to the facts of experience.

In Die Analyse der Empfindungen und das Verhältnis des Physischen zum Psychischen (Jena 1886), Mach analyzes the sensations which constitute the way of man's adaptation to the environment. Mach affirms that geometrical space is very different from our space-sensations or physiological space: "Geometrical space is of the same nature everywhere and in all directions, it is unlimited and infinite. Visual space is bounded and finite, and, what is more, its extension is different in different directions"5.

As regards aural space, we can affirm the same, it is bounded and finite and its extension is different in different directions. Just like our physiological time-sensation is not proportional to the measurement of time, the physiological space-sensations is not relative to the measurement of geometrical space. However, the tone-sensation is analogous to space but as a space of one dimension limited in both directions and asymmetry.

A particular tone-sensation can occur only at a particular point of the said one-dimensional space, on which the attention must in each case be fixed if the tone-sensation in question is to be distinctly perceived. [...] the province of tone-sensation offers an analogy to space, and a space having no symmetry is unconsciously expressed in language. We speak of high tones and deep tones, not of right tones and left tones, although our musical instruments suggest the latter designation as a very natural one ${ }^{6}$.

Just like Mach stated about space-sensation, the French

3 Isaac Newton. Newton's Principia. The Mathematical Principles of Natural Philosophy. Translated into English by Andrew Motte. New York, 1846, p. 77.

4 Cf. Ernst Mach. The Science of Mechanics: A Critical and Historical Account of Its Development. Translated from the German by Thomas J. MacCormack. Chicago-London, 1919, p. 229.

5 Ernst Mach. The Analysis of Sensations and the Relation of the Physical to the Psychical, Translated by C. M. Williams, Chicago, 1914, p. 181.

6 Mach, The Analysis of Sensations, p. 278. 


\section{Philosophy International Journal}

philosopher Henri Bergson exposed three years later the theory of time and consciousness as a pure duration in his doctoral thesis Essai sur les données inmédiate de la conscience (1889). Bergson argued that duration is not extended yet heterogeneous and so its parts cannot be juxtaposed as a succession of distinct parts.

Pure duration, that which consciousness perceives, must thus be reckoned among the so-called intensive magnitudes if intensities can be called magnitudes: strictly speaking, however, is $t$ is not a quantity, and as soon as we try to measure it, we unwittingly replace it by space. [...] We are thus compelled to admit that we have here to do with a synthesis which is, so to speak, qualitative, a gradual organization of our successive sensations, a unity resembling that of a phrase in a melody ${ }^{7}$.

Based on this philosophical theory, many musicologists developed a new theory of specific time in musical perception, that is, of the subjective time that differs from scientific time as a spatial measurement ${ }^{8}$. In 1911 was published the first analysis of time and space in the structures of musical forms written by the Russian musicologist Nadeshda Briusova ${ }^{9}$. Later, the soviet musicologist Boris Asaf'ev wrote: Ценность музыки [The value of music], an essay about time and space in music under the standpoint of musical form as a process.

B. Asafev affirms that if we can remain under the control of the formative musical process, so to speak, listening to music attentively, we have the impression to be in a sphere completely different from the usual world of things that we can see and touch. All this provokes to imagine or feeling another time and space or to be in that system where the sonorous relations are joined under other dimensions of time and space.

The usual dimensions and movements that we perceive every day like long, lengthy, slow, fast, short, lively, etc., in music take another aspect that does not correspond to the impressions of the real world. The musical dimensions do not correspond to the dimensions that we perceive in the empirical intuition. All this indicates that in our perception under certain limits of the musical process emerge an unusual system of sonorous relationship, in which we experience a

\footnotetext{
7 Henri Bergson. Time and Free Will. An Essay on the Immediate Data of Consciousness. London-New York, 1913, p. 106, 111.

8 Among them: Selincourt (1920); Asaf'ev (1923); Gabriel (1925); Koechlin (1926); Souvtchinsky (1939); Stravinsky (1942); Brelet (1957); and Langer (1967). Cf. Arturo García Gómez "Crononomía de la consciencia musical” Devenires. Revista de Filosofía y Filosofía de la Cultura, Año XXI, № 41, enero-junio 2020: 67-101.

9 Надежда Яковлевна Брюсова. Временное и пространственное строение формы/ Научно-музыкальная лекция, прочитанная в Москве 1-го февраля 1911 г. М.: «Скорпион» 1911.
}

world of new dimensions that don't agree with the visual sensation but with the aural sensation.

In this system, we have before us an uninterrupted torrent of sounds united each other from the beginning until the final silence. The movement and streaming are the conditions of this musical formative process. But in each cut of the sonorous flowing, we return to the world of habitual dimensions ${ }^{10}$.

However, this dynamic world of sonorous unions mustn't be a stiff and countable system. Therefore, in the musical representation of space is necessary to avoid concrete things since the essence of musical space is precisely the same process of changeable movement. The music is conceived as well as the perception of a relational system of sonorous unions in its same formative process, and not like a schematic diagram, stiff and finished, or the simple distribution of some material already crystallized.

Thanks to their characteristics of constructive material, the space-time correlations are given like functions and not like substances. These types of union laws expressively appear in the thematic developments of complicated symphonic formations of great space-time diversity.

In music don't exist the representation of immobility, of still things, neither the differences of time, size and distances like tall; low; near; far; past, future; here; there; now; etc. All the basic aspects that are expressed throughout music have a characteristic change. This is precisely the change of a static environment from where these basic aspects were taken, to be taken to the field of functional and pure correlations of sounds. Time and space emerge from the same differentiation's process of spatial forms and temporal successions. Therefore, the music has the capacity of spacetime representation ${ }^{11}$.

In 1926 the German musicologist Hans Mersmann published Angewandte Musikästhetik [Applied Musical Aesthetics], a work about the spatial character of pitch and time focused on the vertical and horizontal dimensions of music. For Mersmann the temporal successions of tones are horizontal, and their simultaneity is vertical. So, the horizontal time dimension of music refers to the melody and the vertical spatial dimension to harmony:

Aus der Wortbedeutung des Begriffs Dimensionen ergibt sich ihre Stellung in der Musik, im Besonderen ihr

$10 C f$. Игорь Глебов [Борис Асафьев]. «Ценность музыки» в: Игорь Глебов сост. De тиsica. Сборник статей. Филармония, Петроград, 1923, c. 23-25.

$11 C f$. Глебов «Ценность музыки» с. 26-34. 


\section{Philosophy International Journal}

Verhältnis zu den Elementen. Horizontale ist Raum und Richtung, Melodie ist Kraft. [...] Der Begriff der Tonhöhe wird mit beiden Dimensionen verbunden: horizontale Ordnung verschiedener Tonhöhen ist Melodik, vertikale Beziehung durch Projektion in die Gleichzeitigkeit ist Harmonik ${ }^{12}$.

The horizontal time dimension is expressed by a force [Kraft] which performs the motion forward, the centrifugal force, and has its source in nature and comprises tones. The vertical spatial dimension originates in the will of the composer that confers restrictions upon the pushing flow of centripetal force and shapes the otherwise boundless stream $^{13}$.

Mersmann's conception of space [Raum] in music is ambiguity. He sees music as a projection of energy or force in the space. Therefore, his notion of space in vertical is not dimensional at all. A horizontal force is considered masculine, developmental, and dynamic while vertical space is feminine, non-developmental, and static. The space (vertical) like background and complement of force (horizontal), provides a double perspective in which musical form can be perceived ${ }^{14 .}$

In October 1930 was held in Hamburg the Fourth Congress of the Society for Aesthetics, dedicated to the notion of time and space in arts as a central theme. There were presented two lectures about the space in music: Das neue Raumgefühl in bildender Kunst und Musik by Walter Riezler; and Raumtiefenhören in der Musik by Max Schneider, published in Zeitschrift für Ästhetik und allgemeine Kunstwissenschaft (Band 25, 1931).

The first lecture of Walter Riezler, about the new spacesensation in graphic art and music, suggests an analogy between space in painting and music. In the Renaissance, the Italian painters achieved a new space-sensation of the third dimension in the painting by linear perspective. More than one hundred years later the musicians of the $17^{\text {th }}$ Century achieved the new space-sensation in music by tonality, similar to linear perspective.

W. Riezler affirms that our language is directed at the optical conception of the world. Therefore, Riezler proposes the term space-tone [Tonraum], to define the space in music. Before the innovation of harmony [in der 'vortonalen' Musik], the linear (counterpoint) music was two-dimensional, in horizontal and vertical movement, but the harmony gave to

12 Hans Mersmann, Angewandte Musikästhetik(Berlin: Hesse, 1926) S. 10.

13 Cf. Martina Stratilková "Hans Mersmann and the Analysis of the New Music" Musicologica Olomucensia 22, December 2015, p. 109.

14 Cf. Anna Maria Harley. Space Spatialization in Contemporary Music: History and Analysis Ideas and Implementations. Ph. D. Dissertation, McGill University, School of Music, Montreal, Quebec, Canada, 1994, p. 58. music the depth of the third dimension, the deep-dimension [Tiefendimention] of tonality.

But after three hundred years of music tonality, the musical art, beginning with Debussy, leaves the development of musical contrasts as much in horizontal leitmotivs as in vertical harmonic functions, with the new colorist harmony of impressionism, and the clear depth of the third dimension, the space-tone [Toneraum], disappeared.

Alle tektonischen Gliederungen sind aufgehoben, die Töne sind melodisch gleichwertig und gleich gewichtig, von verschiedenen „Richtungen“ im Raume kann mehr gesprochen werden, - der klar dimensionierte Tonraum besteht nicht mehr ${ }^{15}$.

In the same way, some years before the pictorial impressionism had left the linear perspective for a new expression of color, and a few later for geometrical form construction (Cézanne). Thenceforth the painting changed from a static space-representation of Renaissance to a new representation of space, that is, from a linear perspective of one single standpoint to a dynamic multi-perspective, the so-called cubism, a new dynamic multidimensional space construction as describing Albert Gleizes and Jean Metzinger in $\mathrm{Du}$ 'Cubisme.'16 Since then the modern space in graphic arts like Futurism, Constructivism, etc., etc., was no more three-dimensional but multidimensional. In music, this multidimensional space construction appeared first in the works of Stravinsky ${ }^{17}$.

The second lecture, Raumtiefenhören in der Musik presented by Max Schneider, is about space perception in music and their differences between 'high' and 'deep'. Schneider affirms that the notion of spatial high-pitch movement [Tonhöhe] goes in two directions: in the horizontal melodic changes of high-pitch and in the vertical

15 Walter Riezler, "Das neue Raumgefühl in bildender Kunst und Musik" in Vierte Kongress für Ästhetik und Allgemeine Kunstwissenschaft Hamburg, 7-9. Oktober 1930. Bericht im Auftrage des Ortsausschusses Herausgegeben von Hermann Noack. Beilageheft zur Zeitschrift für Ästhetik und allgemeine Kunstwissenschaft Band 25, Stuttgart, 1931, S. 194.

16 Albert Gleizes \& Jean Metzinger. Du "Cubisme". Paris: Eugène Figuière et Cie, éditeurs, 1912 (English translation: Cubism, London: T. Fisher Unwin, 1913/ Reprint by Robert L. Herbert (ed.). Modern Artists on Art: Ten Unabridged Essays, Prentice Hall Press, 1965, pp. 1-18).

17 The first analysis of the Stravinsky's musical cubism was published in 1933 by the soviet musicologist Arnold A. Alshvang, and later in 1982 by Mihkail Druskin. In Western Europe, the German musicologist and philosopher Theodor Wiesengrud Adorno published his analysis of Stravinsky's musical cubism in 1949. Cf. Арнольд А. Альшванг. «Идейный путь Стравинского» Советская Музыка, 1933, № 5, с. 90-101; Theodor W. Adorno. Philosophie der neuen Musik, Tübingen, 1949 (Strawinsky und Wiederherstellung); Михаил Друскин. Игорь Стравинский. Личность, Творчество, Взгляды. Ленинград «Советский композитор» Ленинградское отделение, 1982. 


\section{Philosophy International Journal}

harmonic distribution of tones in chords. But tones and tonesensations are two-dimensional since they are 'high' and 'deep' or 'vertical' and 'horizontal' in the same plane.

Nonetheless, Schneider says that there is a complex of possibilities in this two-dimensional plane owing to special characteristics of musical spaceperception [Raumempfindung] and space-representation [Raumdarstellung]. But it is only an art of space-effect [Raumwirkung] since its space-representation is just an acoustic parallel of visual perspective, literally a

[...] deep-representation [Tiefenvorstellung]: a deep-listening [Tiefenhören] in another plane or expressed in another way: the differentiation of one plane united to everywhere or the perception of successive sounds not only like an Echo but the representation of foreground and background. There is as if this art of compressed sounds [Höreindrucks] comes true, and as far as certain grade and limit are not clear until today ${ }^{18}$.

One of the systematic studies about possibilities of deep-perception, says Schneider, was the Tonpsychologie of Carl Stumpf, confirming briefly that "several simultaneous tones are perceived and then without great differences becoming clear" 19 . To understand clearly the deep-listening [Tiefenhören], Schneider associates it with visual guiding and localization, the directions, and distance's perception [Richtungsvorstellung und Entfernungsvorstellung].Schneider says that the variable adjustment of eyes in different points of fixing-line isn't clear for deep-listening. Stumpf rejected this variable fitting in both ears on several simultaneous sonorous tones like occurs in visual localization of objects.

But the fixing line for deep-perception is almost the same for eyesight than for hearing, just like occurs on guiding points. The points are the tones. So is completely natural the aural localization of objects by hearing. The fixing-points or the listened tones in space by both ears are interconnected, and this interconnection is the harmonious order and togetherness, the harmonic simultaneous sounds, not only in consonant chords but even in dissonances.

Schneider confirms which already said Stumpf in his Tonpsychologie, that deep-perception of sounds is not only in height but in the differentiation of quality, intensity, darkness, and color of tones too. However, tones are not bodies. Only through listening is perceptible a sonorous phenomenon,

18 Max Schneider, "Raumtiefenhören in der Musik" in Vierte Kongress für Ästhetik und Allgemeine Kunstwissenschaft, Opus zitiert, S. 207. [My translation]

19 Carl Stumpf, Tonpsychologie, Band II, Leipzig 1890, S. 85. [My translation, cited by Schneider] and the listening had developed to the hearing perception of nearness and distance until a disappearing point. On the other hand, sight, especially the deep-sight, had developed for perception and representation of bodies that keep their structures and proportions exactly like musical structures of intervals and other tone formations ${ }^{20}$.

In 1931 the Austrian anthropologist Siegfried Nadel published an article about the notion of musical space, entitled: Zum Begriff des musikalischen Raumes, as an answer to the Fourth Congress of the Society for Aesthetics, published in Zeitschrift für Musikwissenschaft. Nadel argued that there is a basic duality in the notion of musical space: the empirical subjective, psychological or phenomenological space of habitual conception; and objective, geometrical or physical space in real listening. Each of these notions denotes the changeable and limited facts of our spatial perception and has an order-schema [Ordnungsschema] of all things in our pre-established order-place as a systematic aprioristic structure ${ }^{21}$.

But this notion of physic space in general world perception hasn't any place since it is a conceptual construction. However, in music, this notion of schematic construction is transformed into a singular knowledge of real representation. The dual notion of space in music has an expressive existence in our experience, and just this duality gives to music space their specific aesthetic character.

Nadel affirms that we have in habitual music-conception of space, the tones and sounds in their exact place just like other perceived objects. The experience of this type of space is not exclusively for music. Another question is the localization of tones by binary perception too. However, we have another special type of space in music throughout the established order-schema of pitch pipes. Here we have an objective or geometric space corresponding to the space given to each tone and the aprioristic place that they must have. Nonetheless, the phenomenological and physical dimensions like location, mass, and volume, are not commensurable. The question is if we have a real experience of space in music, or just is only an analogy with the real space-perception. In any case, Nadel says that this symbolic space, the high-pitch direction of scale, is their most outstanding characteristic ${ }^{22}$.

The next question is about the spatial analogy of orderscheme. The phenomenological space is the well-known three-dimensional space of our perception. But the specific spatial tone denotes other ways of perception. Nadel

20 Cf. Schneider "Raumtiefenhören in der Musik", S. 208-212.

21 Cf. Siegfried F. Nadel. "Zum Begriff des musikalischen Raumes" Zeitschrift für Musikwissenschaft, 13 Jahrgang, Leipzig, 1930-31, S. 329.

22 Nadel, “Zum Begriff des musikalischen Raumes”, S. 330. 


\section{Philosophy International Journal}

indicates three forms. First, the high-deep order appears as a new dimension of intensity, like an added sonorous color, and this is how we perceive the sonorous volume. But in all homogeneous-continuous tones, there is not this new dimension, rather it influences the high location of certain tones and the autonomous variation of sonorous intensity and color since the high tones have in the same and permanent conditions great intensity and small deepvolume, and vice versa.

Second, just the linear high-deep dimension is not sufficient; in the octave returns, just like inside the octave, the distinguished and discreet points penetrate the rectilinear dimension and raise their continuous friction. This new determination of tone was taken soon to symbolizes the spatial tone in one spiral by Drobisch. ${ }^{23}$ However, the knowledge of the entire autonomous variability of this new dimension certainly was expanded in studies of pathological experiences of primitive music.

Third, the harmonic dimension that doesn't represent more dimension. There is only the construction of a complex created inside a high-volume-quality space. The gravitational pull gives a new dimension to original tonality understood as harmony. Their dimensional sense introduces another art because one tone is not itself dominant or tonic but only throughout its relation with other tones in the tonal system. This gravitational pull constructs new coordination, in which the grades of tonality with their center (tonic, sub-dominant and dominant), finally omit the strange grades. There is clear that in this dimension all its structure mustn't be homogeneous. We recognize that in all this tonediversity of space constructions with complicated levels, multidimensional and non-homogeneous space structure, like in modern physic says, curved, it mustn't be Euclidean space $^{24}$.

In that same year of 1931, the Swiss musicologist Ernst Kurth wrote a chapter about musical space phenomena (Das musikalische Raumphänomen) in his work: Musikpsychologie. Kurth affirms that "there are several material roots for musical space phenomena. Space and material sensations in musical psychological phenomena are based on listening, and they don't emerge from spontaneous fantasy"25.

Nevertheless, musical space belongs to psychic processes and it is essentially ambiguous. Music space differs

23 Siegfried Nadel refers to the work of German mathematician and philosopher Karl Ludwig Drobisch: Über die mathematische Bestimmung der musikalischen Intervalle (1846) [On the Mathematical Determination of Musical Intervals].

24 Nadel, "Zum Begriff des musikalischen Raumes", S. 330-31.

25 Ernst Kurth. Musikpsychologie. Berlin: Max Hesse Verlag, 1931, S. 116. from visual space; however, it includes similar dimensions: pitch as the musical analog of height and time of width. Kurth points out that in our world view we have a common opinion that space is static; something similar is in our world view of spatial art like in painting and even in music, that it is performed continually inside of one static space.

In his extensive chapter, Kurth analyses the motion energy as the main reason of musical space-sensation; the indistinctness of space representation (dimensions); the indistinctness as a basic characteristic of musical space phenomena; the relation to the external conceivable space; and the relativity in the analogies with height and width ${ }^{26}$.

Then the deep-dimension; the impossibility of visualization; the associative representations of spatial depth; the mass-impression and three-dimensionality; the uncertainty of dimensional impressions and secondary character of spatial representation; the contrast between musical and external space (localization); and the autonomy of musical space representation from the spatial sense for tone source. ${ }^{27}$

Finally, the interval survey concerning spatial representation; the comparative dissociation of tones; the discrepancy between nature and origin of musical space representation; the independence of musical space sense; and the spatial impression of imagination, vision, taste, and hearing sense in relation with energetic space ${ }^{28}$.

After the Second World War, the German composer Paul Hindemith dedicated some lines about the spatial perception of music, in his work A composer's world. Horizons and limitations, written in English and published in the USA in 1952. Just like in Lessing's Laocoon who says "that colors are not sounds, and ears, not eyes", Hindemith begins saying that the effects of arts on our receptive capacity may employ the element of space only as do visual arts; or the element of time only, as does poetry; or in both as does the drama and moving pictures. However, in music, those effects cannot be caught as easily as the other arts.

We cannot deny that musical progressions evoke in our mind sensations of both a temporal and spatial nature, but the following investigation will show that the sensations of musical time and musical space are not identical with time and space as felt in our everyday life or the aesthetic effects of non-musical works of $\operatorname{art}^{29}$.

26 Kurth, Musikpsychologie, S. 116-122.

27 Kurth, Musikpsychologie, S. 122-130.

28 Kurth, Musikpsychologie, S. 130-133.

29 Paul Hindemith. A composer's world. Horizons and limitations, Harvard University Press, Cambridge, 1952, p. 50. 


\section{Philosophy International Journal}

Hindemith affirms that the effect of musical time on our feeling, expressed in metrical successions, is not essentially different from 'normal' time. But there is another form whose effects are quite different from those of normal time that is expressed in forms of rhythm. This is the same with the effect of musical space on our sensation of ascending and descending tones in their pitch relation. Hindemith says that "there are in music no such spatial distinctions as high and low, near and far, right and left that correspond with the same definitions in real non-musical space" ${ }^{30}$.

Just like Mersmann and Kurth stated, Hindemith confirms that the motion energy which moves from one tone to tone is the main reason for our musical space-sensation. The physical effort necessary to change from one tone position to another equals the sensation of physical change of objects in their spatial position. This spatial effect produced by the physical effort of movement is similar to the emotional effects of music. There is no image of feeling could be evoked in our mind, unless a real feeling suffered earlier: "Only about our experiences in real space can we have an analogous image of space in our mind, evoked music" ${ }^{31}$.

Musical space is felt as three-dimensional because the movement of tones, like the movement of things, goes up and down in a vertical movement of high-pitch scale, right and left in horizontal movement of musical progressions of harmony and melody, and finally forth and back, like Riezler affirmed, that produce the feeling of spatial depth in music, similar to the effect of depth by the perspective in painting.

In painting the impression of visual depth is created by so drawing all receding lines of the picture's objects that their prolongations meet in one single point - the vanishing point; and in musical perspective, all harmonies, whether resulting from the vertical (up and down) distance between tones, or by the summing-up effect of consecutive tones in melodies, will by our analytic capacity be understood as in close relationship to tones which, by frequent recurrence, or by favorable position in the structure, or finally by the support received from other tones, will be felt as tones superior to the others; tones that occupy the place of fundamental, of tonics ${ }^{32}$.

For Hindemith, the main question is if we can conceive music without reference to any real or imagined space. He wonders if: is possible to think music as something completely removed from any spatial conception? And if it is impossible: must we necessarily project all our threedimensional experiences into our musical space? Could we

30 Hindemith, A composer's world, p. 52.

31 Hindemith, A composer's world, p. 53.

32 Hindemith, A composer's world, pp. 53-54. restrict ourselves to an image of three-dimensional space similar to the effect of perspective in painting?

And his answer is: "Since music revives in our minds the images of feelings which are inevitably connected with memories of space in which the originals of these images occurred to us, imaginary spaces will always show up simultaneously with the images of feelings" ${ }^{\prime \prime 3}$.

Certainly, in the antique western music before the harmony, like in other cultures where the harmony is either unknown, the music consisted only of melodic lines and the effect of the sounding perspective of tonality was impossible. Indeed, many works of modern pictorial art renounce consciously to this effect, as musical serialism renounces to tonality too. But now, after four hundred years of harmonized structures, when we had tasted the fruit of sounding perspective and lost the innocence of pure melody:

[...] it is quite impossible to understand melodic lines without harmonic and tonal implications. The intervals produced by the successive tones of melodies have, in addition to their melodic function, harmonic significance, and we cannot fail to perceive it. [...] In painting, it is up to the painter to decide whether he wants to have a perspective as a part of the pictorial effect or not. In music, we cannot escape the analogous effect of tonal unification, of tonality. The intervals which constitute the building material of melodies and harmonies fall into tonal groupings, necessitated by their physical structure and without our consent ${ }^{34}$.

Here Hindemith associates the sounding perspective with the force of gravitation. Tonality is indeed a very sensitive form of gravitation; tonal gravitation that moves from one tone to tone, and this is the main reason for the spatial effect in music. The spatial effect of two-dimensional movement in melody by horizontal and vertical, and the effect of depth produced by the third-dimensional perspective in harmony too.

Hindemith says that what we feel as the spatial effect of moving lengthways, is accomplished musically by horizontal movement from one tone to another, just like the effect of time in music too. Musical time and musical space are interlocked in the horizontal, in a way that is unknown to normal time and normal space. But the idea of infinity and relativity of normal time and space are no perceptible to our senses. These concepts can be expressed only in numbers or words; however, we can never experience it.

Yet music seems to be the only earthly form of expression

33 Hindemith, $A$ composer's world, p. 54.

34 Hindemith, A composer's world, p. 55. 


\section{Philosophy International Journal}

which in the properties of its constructive material permits us to have sensations that are a very faint allusion to the feeling of beings to whom the universal concept of the relativity and interchangeability of time and space is in ordinary experience ${ }^{35}$.

At this point, we must return to Ernst Mach, who affirmed that pure mental constructions of time and space cannot be produced in the experience. Geometrical space is unlimited everywhere and in all directions. This conceptual space is very different from spatial sensations which constitute the way of our adaptation to the environment. Visual and aural space perceptions are bounded and finite, and their extensions are different in different directions.

All scholars, musicologists, and composers have confirmed in diverse ways that spatial perception in music is similar to the spatial perception of our real experience. But all of them refer only to the spatial perception of sounds in music, that is, only to the movement that we feel in this perception, and not to the movement that we imagine when we listen to music.

Of course, this question represents a great dichotomy in musical aesthetics. Now we know that the perception of space in music is analogous to our real experience. But this analogy is only between the movement of things in the real experience and the movement of sounds in the empirical perception of music. The sounds are analogous to things, and like things, the sounds occupy a place in the space.

However, the sounds are not things, and they don't occupy only a place in the air but denote actions or events. The sounds are signs of something else and their combination in music denotes more than the sound itself. Therefore, music is much more than a simple combination of sounds or the 'beautiful play of sensations', like I. Kant stated in Critique of Judgment, or even worse, the famous Hanslick's 'arabesque' in Vom Musikalisch-Schönen ${ }^{36}$.

In 1911 the Russian painter Wassily Kandinsky affirmed that "Painting as an art is not some vague projection into space but a power, so strong and full of purpose that it serves the refinement of the soul. It is its language that speaks to the soul" ${ }^{\prime 7}$. This statement is precisely a paraphrase of music too. Music as an art is not only a vague projection of sounds into space but a power that serves the refinement of the soul.

35 Hindemith, A composer's world, p. 57.

36 Cf. Eduard Hanslick. Vom Musikalisch-Schönen. Ein Beitrag zur Revision der Ästhetik der Tonkunst. Leipzig, Rudolph Weigel, 1854.

37 Wassily Kandinsky. Concerning the Spiritual in Art, Published by the Solomon R. Guggenheim Foundation, for the Museum of Non-objective Painting, New York City, 1946, p. 93.
Music is the language that speaks to the soul. Fifty years before, the Russian music critic Alexander Serov, in his article about the Opera in Germany and the musical innovations of Richard Wagner, affirmed:

Music, besides to be a play of sounds is the language of the soul, the language of the heart that coincides partly with the oral speech and partly with the non-commensurable and ineffable agitation of the soul, with the secret world of the soul which there is not affordable to the word with its rational symbolism ${ }^{38}$.

If we conceive music only like the art of beautiful combinations of sounds, like an ornamental art without any contents, then the musical tones only can mean or denote themselves in which the movement is similar to the movement of things in the space. But if we conceive music like a language, like an art capable of communicates knowledge, the movement of tones denotes something else, actions, or events that happened in a particular space and time.

This is the artistic space and time in music, like the artistic models in a literary story where the action happens in another space and another time completely different from our real experience. As a composer, Paul Hindemith outlines this artistic space and time in music.

Within the framework of musical time and musical space, the musical action takes place, in which the composer's ideas are the actors who by harmonic, melodic, and rhythmic circumstances are turned into tragic or comic characters, their tragedies and comedies being of the kind that lives in the stored-away world of the listener's images of emotions ${ }^{39}$.

In 1962 the Hungarian musicologist József Ujfalussy analyzed the unity of space and time in music, in his work The Musical Image of Reality. The logic of the Meaning of Musical Art. ${ }^{40}$ In this intrinsic unity of space and time, Ujfalussy points out that musical space, in particular, owing to its nature, is an abstraction of the special properties of sonorous material. As regards the time, it seems that the question about musical time was resolved a long time ago. Now all we know that famous sentence: 'the music is the art of time'.

At first sight, this affirmation seems to be an incontrovertible truth, just like the sentence: 'the painting

\footnotetext{
38 Александр Н. Серовъ. « Опера и ея новейшее направленіе въ Германіи. Критическій этюдъ » Русское Слово, Литературно-учений журналъ, Санкт-Петербург, № 7, Июль 1859, Отделъ III, с. 88-112 ; с. 92 (теперь в : А. Н. Серовъ. Критическія статьи, Томъ второй (1857-1859 гг.), С-Петербургъ, 1892, с. 1192-1210; с. 1195). [Мy translation from Russian]

39 Hindemith, A composer's world, p. 57.

40 József Ujfalussy. A valóság zenei képe. A zene müvészi jelentésének logikája; Zeneműkiadó Vállalat, Budapest, 1962.
} 


\section{Philosophy International Journal}

is the art of space'. But even we could add another wellknown sentence product of two previous sentences: 'the architecture is petrified music'. Although in essence, these affirmations are characteristic sentences of that vision world about art which only considers one and unique aspect of artistic representation.

In the same expressions as 'art in the time' or 'art in the space,' there is a contradiction (contradiction in adiecto) because the art is an artistic generalization using models, and not of concepts. Consequently, it [the art] not addresses to the abstract mind in concepts, but the model perception. Space and time are categories of the existence and contemplation too, which we can observe in our consciousness separated each other thanks to any scientific research, though separately perceive or contemplate it, hardly somebody can do it to date. Subsequently, speaking about the artistic model like a replication of reality, we can only consider the model that in our consciousness forms the inseparable unit of two fundamental categories of existence ${ }^{41}$.

When we speak about artistic models (or ideas) as a reflection of reality, we can only take into account that artistic model which is based on the intrinsic and indivisible unity of two fundamental categories of existence: space and time. Certainly, in the aesthetic perception always prevail one of these two categories. Therefore, the musical space is a possible space, a potential space, just like the time in painting is possible potentially.

However, if we start our analysis from a superficial appreciation, we will never understand the essence of art. This unilateral appreciation of music is more evident in Hanslick's definition, who absolutizes the temporal aspect of music and uses it to deprive music of its contents: "Der Inhalt der Musik sind tönend bewegte Formen"42.

In contrast to the definition of Hanslick is a very essay to resolve the problem. Assuming that the contents of music are not something more than a sonorous moving form, then the same movement must be in time and space since none of these categories determine by itself neither the movement nor the form. On the other hand, since we observe the movement of those things that should move, we cannot exclude them from music because the definition becomes unbalanced. Well, do not exist such a coefficient that through one metaphysical operation the form may become in some

41 Йожеф Уйфалуши. Единство пространства, времени и действия. O содержании музыкального образа. в сборнике «Музыка Венгрии», Москва, «Музыка» 1968, с. 190. [My translation from Russian]

42 Hanslick, Vom Musikalisch-Schönen, S. 45. (Cited by Ujfalussy: Уйфалуши, Единство, с. 191) identical to contents ${ }^{43}$

Ujfalussy affirms that the objective sources of music are the human activity expressed by intonations. In other words, by tones which movements are similar to the movements of human activity. Therefore, the musical space is not abstract. It is potentially a possible space, just like the time in pictorial arts is potentially possible.

In the same way, the time is always a time of something that exists and occurs, and consequently, it moves, alike musical rhythm that underlines the periodicity of movement, is a rhythm of something that moves and happens. We listen to this movement in the sounds and join them with muscular movements. But the rhythm is not absolute, since it is neither the time measuring itself nor the primitive portrait of music as a 'pure temporary nature' 44 .

In essence, the music is a reflection of nature and human activity expressed by intonations. The musical intonation is indeed the movement between tones, and by this movement or by this energy of attraction (the tonal gravitation that moves from one tone to tone), the tones denote the spatial character of the musical image. But the musical intonation emerged from intonations of the voice. In other words, the musical movements of tones (intonations) are a sophisticated imitation of the movements of language, of its intonations.

All we know that the aesthetic perception of reality is through our five senses, being the most relevant the senses of sight and ear, but actually, the five senses act together although not always consciously. All our senses take part in the empirical intuition, in the sensitive perception of reality, and from their combination, the mind selects the most relevant intuitions that conform to the final image in a certain space and time. Therefore, the objects fit finally with the nature of our intuition.

In this way, we perceive from the things only that we had selected from them through our five senses. This selection of intuitions, or the way how we know the world, that's to say, that the subject selects from the things in the same act of knowing Kant called transcendental. According to Kantian aesthetics, the pure intuition a priori realizes this selection of empirical intuitions that perceive the form of things and structures them in space-time.

However, this pure intuition that selects the perceptions from our senses, and structures the form of things in the space and time, is a priori in the same process of perception,

\footnotetext{
43 Уйфалуши. Единство пространства, с. 191-192. [Му translation from Russian]

44 Cf. Уйфалуши. Единство пространства, с. 195, 201.
} 
so to speak, it is an intuition already formed that no depends on the sensory experiences of that moment. In this sense, the Kantian pure intuition is a structure of mind. Nevertheless, it not means that pure intuition is innate, that it couldn't be shaped before in the experience.

This structure of our mind is essential in the sensitive perception of the world since it shapes the whole picture through a selection of many sensations that perceive our senses. And in this selection, the senses compensate each other: the sight can replace the ear and vice versa. Without this compensation, we would never have the complete picture of reality and much less the certainty of our sensitive knowledge.

But in contrast with the aesthetic perception of reality, in which take part the five senses, in the arts only take part one or two senses, the sight of the ear, that are predetermined by the form of representation in each particular art. In the case of music, we cannot see the sounds, we cannot touch the music and even less smell it or taste it, although in 1881 Eduard Hanslick affirmed that he had heard the stench in the Tchaikovsky's violin concert ${ }^{45}$.

Therefore, in the aesthetic appreciation of art, instead of selects sensations, the transcendental consciousness fills $a$ priori the sensory vacuums of music, and in our imagination, we can see the movements of things or events that we hear. We can listen to music only in the empirical intuition, but our mind compensates, consciously or unconsciously, the absence of other senses, filling the sensory vacuum of space.

This way, in our imagination or fantasy we complete the spatial intonation of music. Without pure and $a$ priori intuition in artistic appreciation is impossible to fill the sensory vacuums in which the nature of artistic representation imposes us. Each art has its limitations and virtues, and precisely in each limitation, there is the seed of artistic imagination.

The aesthetic appreciation of art is a very complex process that requires moreover the innate sensibility, and the specific knowledge of art that is contemplated. We know that one thing is to see and another thing is to observe. The first is the empirical intuition; the second is the eidetic intuition. The same is for music. Everybody can hear a symphony but not everyone can listen to it. To hear a symphony, the empirical intuition requires a time that is measured in minutes. However, to listen to it, the eidetic intuition requires of intonation's sensibility and previous knowledge that fills $a$ priori the sensory vacuum of music. The attentively listening of this symphony involves the imaginary space and time in which the musical events (or intonative narration without words) take place.

These events depend on the musical programme of the symphony, even on the so-called 'absolute music' supposedly non-representational, and the imagination of listeners. This is the substratum of eidetic intuition that structures a priori the intonative events for the explicit musical programme proposed by the composer, or for the listener's imagination that adds, consciously or unconsciously, to the listening of work, completing in this way the narrative intonation of the symphony.

However, the space and time in these stories are completely different from the space and time of empirical intuition. This we are speaking about imaginary or fantastic space and time. When we listen to music, we perceive space and time through the movement of sound. We recognize the character or intonation of something that is moving, but we cannot see, and we don't know for certain what thing is or what is about.

This uncertainty or ambiguity has a huge artistic potential since the consciousness tries instinctively to fill the visual vacuum with the imagination and fantasy, that produce at the same time a great emotional expectation before this ambiguity of images or pictures. Even more, to this ambiguity, we add the representation of an unreal space, since there is not about the movement of one real thing in the space that we can measure with the minutes of the mechanic time.

This imaginary or fantastic space and time of musical artistic representation are completely unreal and paradoxical where: before, after, here, there, etc., fell into the depth of unconsciousness. Therefore, the real-time musical performance doesn't coincide with the imaginary time that produces those images and the mind takes into the spatial vacuum of music. In a musical piece of two or three minutes, we can remember or imagine all our life, just like in a colossal romantic symphony to recall one single moment of our intimate existence or the sublime feeling of infinity. 